\title{
Environmental Justice and the Discourse of Peace Building in Ethiopia
}

\author{
Mengistu Adugna Dibaba \\ Lecturer at the Department of Civics and Ethical \\ Studies, Madda Walabu University; Bale Robe, Ethiopia
}

\begin{abstract}
This paper is intended to explicate the nexus of the issue of environmental justice and peace building practices in Ethiopia. In line with this, it expounds the significance of environmental justice dimension of peace building process in the country. Better understanding of the links between environmental issues and human security is vital for effective conflict prevention, peace building and post-conflict rebuilding. Yet, in this country, significant attention was not given to this environmental dimension of peace building process. Since every single of conflicts that happen in the country is politicized, this ecological approach is often obscured. Furthermore, there is no significant literatures and research investigations on this issues .Thus, for the fact that there are different environmental injustices that highly contribute for a range of violent conflicts in the country, it is argued that comprehensive restoration of lasting and sustainable peace is impossible without restoring environmental justice and solving environmental problems therein. In this article, by using analytic approach and personal observation, the findings of the study indicate that there is a considerable prevalence of environmental injustices such as pollution, resource depletion, coercive eviction of local people from their farm land and settlement, unfair or disproportionate share of environmental advantages and disadvantages, oppression of some group of people to dominate and exploit their resources, and forceful confiscation of one's land and resources around the border,which one way or another contribute a lot for violent conflicts and instability throughout the country.
\end{abstract}

Keywords: Environment, Environmental Justice, Peace, Peace building, Conflict

DOI: $10.7176 /$ RHSS/10-11-05

Publication date:June 30th 2020

\section{Introduction}

Nowadays the concept of peace building is the central focus of many writings in the world. Likewise, how to address violent conflicts and enhance sustainable peace is another pressing issue. Scholars actually suggest different approaches and ways to build peace. These include political, social, economic and ecological aspects. In Ethiopia, both government and other concerned bodies often give due emphasis to socio-economic and more importantly, to political approach for reducing conflicts and making peace. Although many vicious conflicts that happened in the country have environmental inclination, government usually put this fact aside, focusing on a sole political efforts and pursuing political solution as such. This narrow consideration of every conflict as caused by political setback is what really obscured the role of environmental aspect. Here, the connection between environment (more importantly, environmental justice) and peace building should be recognized well and environmental justice solution should be pursued accordingly. Ending the violent conflicts, insecurity and creating peace in the country cannot be achieved only by political means but needs incessant environmental efforts.

This article is designed to show how the issue of environmental justice and peace building are interconnected. As such, it tries to indicate the role of environmental justice aspect in reducing conflicts and ensuring sustainable peace in Ethiopia. Beside introductory part, the paper has four sections. The first section deals with the basic concepts of environmental justice and peace building. The nexus of environmental justice and peace building in Ethiopia is discussed in the second section. The third section is concerned with the importance of environmental justice approach to peace building in Ethiopia while the last one is about conclusion of the paper.

\section{Environmental Justice and Peace Building Practices in Ethiopia}

\subsection{The Concept of Environment}

Although there are diverse definitions of environment, it can be comprehensively conceived in two ways: as traditional and modern sense. Traditionally environment is conceived as an objective system of nature or a totality of natural and manmade surroundings of an individual person. It is the green, natural and man-made surroundings or familiar milieu of an individual person or animal, the territory or pathways that give that individual a sense of belonging and comprise his/her home.

But, while the above discussion shows that the environment is the coming together of the natural, the artificial and their interaction at the local and global level, it failed to encompass the sphere of economic, political and social wellbeing, which determine the nature of relation between different groups of people on the one hand and between people and state on the other hand. Hence, in modern sense, the concept of 'environment' encompasses the whole things that include our whole physical and natural worlds, as well as where we live, work, play, go and so and so 
forth. Since recently, its idea has grown to include important components of the environment having the essence of humanity. Especially, with the emergence of environmental justice movement in the 1980s this new conception which views the environment as a natural, social and political composition and their interaction was developed. As such, it encompasses "not only the green, natural and man-made environment but also the social, cultural, economic and political settings in which people live, work, and play (Steady 2009). Mohammed Salih (1999, p.2) also stated that the environment refers not only to the natural and human created values and institutions but also to a domain of competing economic, political and social interests. According to him, the struggle for political power in most of the African social groups is even highly linked to the need to control natural environmental resources for economic and livelihood rationales. Accordingly, conceiving environment broadly both as the entirety of natural world and as an arena of socio-economic and political competitions among different groups is imperative.

\subsection{The Basic Concepts of Environmental Justice}

Environmental justice is one of the topics in environmental ethics. Its concept was originated in United States of America in 1980s (Bullard 2000; Jamieson 2001; Schlosberg 2007; Munnik 2007:2). Different studies concede that it is a by-product of the American Civil Rights Movement of the 1960s which intended to end discrimination of any kind and promote equal rights for all ( Steady 2009:2). The conceptual underpinnings of environmental justice are fair treatment with respect to the distribution of environmental goods and bads and equal participation of all people, irrespective of race, color, national origin, or income, in environmental leadership and decisionmaking.

Basically, environmental justice is the nondiscriminatory distribution of environmental goods and bads, and meaningful participation of all people in environmental decision making. It seeks to ensure environmental equity. Safe work place, clean water and air, availability of natural surroundings or parks, appropriate compensation for environmental burdens and the safeguarding of traditional environmental practices that related to local natural resources are the major instances of environmental goods or benefits (Figueroa and Mills (2001, 427).According to them, on the contrary, environmental bads or burdens embrace exposure to hazards, material and toxic wastes, pollution, health hazards, and work place hazards, the exploitation and damage of traditional environmental practices and depletion of local natural resources and so forth.

In addition to the distributive justice and participatory aspects, the scope of environmental justice incorporates the fundamental concepts such as recognition or inclusion and capabilities. This aims at promoting the recognition and inclusion of marginalized and minority group as well as enhancing their capabilities and functioning for the betterment of their lives and livelihoods. By the concept of functioning, both Sen (1999b) and Nussbaum um (2000) mean that becoming what people want to be (what they value and have reason to value to be) and doing activities that people value and have reason to value. Capability on the other hand is concerned with freedom and capacity to attain what people value to be and do, just like a rich person who has enough money to buy whatever he/she is interested in.

\subsection{Understanding the Concept of Peace and Peace Building}

Actually, defining the concept of peace in its essence is difficult. This is why many thinkers try to define it in terms of the absence of its opposites like war and violent conflicts. However peace is not simply the absence of war or conflict; rather, its concept is deep so that underpin social harmony, economic equity and political justice (Webel and Galtung, 2007) or invokes harmony and bliss in psychological, social and political sense (Grewal, 2003). Peace is what is precious and linchpin of all what are necessary for human well-being and human ideals.

Peace building on the other hand is basically about the process of attaining peace. 'There is no a single universally accepted definition of peace building because many scholars have varying opinions about what it comprises and it is also continuously evolving concept. However, it is basically pertains to what is primarily coined by Johan Galtung. According to him, peace building is an activity to bring about long lasting peace through fixing the root causes of conflict and backing local capacities for peaceful management and resolution of conflicts (Galtung, 1969). This needs the transformed structural and relational means. It emphasizes a clear-cut effort to deal with the root causes of conflict and violence. As such, it pertains to a deep involvement into the dynamic nature of conflict and, hence, needs a much greater degree of social transformation. In this respect, conflict transformation is highly needed to achieve positive peace by eradicating the behavioral, attitudinal and structural sources of violence (Galtung, 1996).

Furthermore, to address the root causes of a particular conflict in the quest of just peace, conflict resolution and transformation process involves a peaceful means such as dialogue, negotiation and mediation. It is intended to manage structural, behavioral and attitudinal nature of conflict through changing the destructive conflict into constructive one. In this regard, peace building process has twofold ways: working to address destructive conflict and to advance the existing peaceful practices or to promote new alternative.

To alleviate the current, past and looming or potential violent conflicts and thereby advocate enduring and 
sustainable peace thereof, peace building fundamentally embraces all local, state-based or international policies and strategies. To do so, both bottom-up and top-down methods are strongly employed so as to encourage dialogue, negotiation, mediation and peaceful relationships between conflict parties and the affected societies. It involves the potential of different actors. According to Curtis (2012), besides avoiding a lapse into violent conflict (peace consolidation) peace building here contains programs that fundamentally empower marginalized groups, encourage inclusive access to resources and institutions, redistribute land ownership and income, and end discrimination against any group of people.

\section{The Nexus of Environmental Justice and Peace Building in Ethiopia}

Basically, the issues of environmental justice and peace building are interwoven. At their core, there exists the concept of humanity. Both of them fundamentally deal with human security and livelihoods. They give priority for human well- being. They strive to bring about peace, justice and fairness so as to ensure human welfare.

On the other hand, environmental injustices can be often the cause of violent conflicts. United Nations (1987) in the report "Our Common Future" identified environmental problems as a potential cause of violent conflict. "The natural environment has often played a key role in conflicts throughout the world" ( Alida et.al, 2009, p,6). The question of environmental justice is the question of fairness, justice, equality, inclusion and equity, to wit, the question of live or die. Thus fostering environmental justice is one way or other, fostering peace. Therefore better understanding of the connection between environmental change and human security is very important for effective conflict circumvention and peace building.

As we can observe from history, the scarcity of some natural resources and environmental crisis leads to conflicts between different societies around the world. Likewise, injustice, inequity and oppression regarding the use of high-value natural resources as well as other resources like land can make sober and long-lasting conflicts among societies. Climate change also intensifies territorial and boundary conflicts. For instance, scarce resources, declining water resources, diminishing arable land, migration and so forth create conflicts between two states, and within one state's region, tribes, clan etc. It stimulates a risk of violent conflicts and even ethnic cleansings. The negative impacts of climate change, including degraded ecosystems, through jeopardizing livelihoods and human security also leads to involuntary migration and population displacement (Werz and Conley, 2012; Burrows and Kinney, 2015), which at the end, leads to serious violent conflicts.

Most of conflicts happened in Ethiopia, though often obscured by more visible issues such as ethnic tension and power politics, are one way or another linked to environment and environmental injustice. In a broad sense, environmental injustice here is depriving of all your environmental advantages (environmental resources including land) or forced confiscation of your environment and environmental resources by another body, to wit, by government or other dominant body. It can be also termed as forced and unjust getting of disproportionate or losing what is environmentally belongs to you. For example, the case of 'Ethiopian Integrated Master Plan', which, as Amnesty International reported, aims to expand the capital, Addis Ababa, into Oromia regional territory is also part of this issue of forced confiscation of environmental resource, land. If the plan became effective, it would have caused the eviction of thousands of farmers and other people from their land and settlements. At that time, this plan incited so many protests across Oromia region in April and May 2014, resulted in dozens of deaths and thousands of injuries (Amnesty International 2014). Because of this unjust plan, huge and pervasive violent conflict stimulated which at the end, though backed by deferent political movements, resulted in the fall of the TPLF government. The expansion of Addis Ababa and other notable cities in Ethiopia is even currently ongoing implicitly. This is against environmental and cultural rights of local people.

The case of MIDROC Mining Company in Guji Zone of Oromia Region can be mentioned here. There was environmental pollution and toxic damping there that harmed the health of thousands of people around the area. It did serious injustices to the local dwellers. Lega Dembi mining operation has exposed the local community to dangerous levels of multiple toxins, including cyanide, arsenic, and mercury (Center for International Human Rights Northwestern, 2019, p, 4). As a result, serious people's protest and riot was incited in May 2018, which at end contributed a lot for political and social instability in the country.

There are also other different already instigated conflicts that concerned with the question of land and land resources. For instance, we can take the violent conflicts between Oromo and Ethiopia Somali people. No matter how it is masked by political intent, the root cause is the question of land (the so called border). This conflict was resulted in many deaths and more than a half million eviction of people from their land and settlements. It brought a huge social, economic and political crisis to government and more to both nations. Similarly, there were also tough conflicts between Guji Oromo and Wolaita, Guji Oromo and Gedeo people, Wollega Oromo and Benishangul Gumuz, and so forth. The source of these conflicts is basically the claim of environmental justice, the claim of proportionate share of environmental goods and reclaiming of what they lost in the past. The cause of border conflicts between Ethiopian people or nations is not a mere simple scarce resources like water and grazing land, as most of environmental peace building advocators suggested. The issue of environmental injustice is more deep and dynamic; it goes beyond the issue of scarce resources as I mentioned it above. It needs restoring lasting 
and sustainable environmental justice by government and other all stakeholders. Environmental problems can be used as incentive for social interaction, cooperation and peace, as many scholars suggest, does not mean that they are not the cause of conflict, but to recommend that these environmental causes con be put in to advantage to encourage antagonists to come to gathers to work cooperatively for the solution. However, the concern of environmental justice here is broader, diverse and dynamic in its nature for the fact that it touches the whole aspects of human life and livelihoods. Therefore, the enticement for social cooperation and peace is to provide a meaningful solution to environmental injustices such as land grabbing, climate change injustices, eviction of local people (especially farmers, poor and marginalized societies) from their land and settlement without their interest and appropriate compensation, and environmental resources oriented border conflicts.

One of the dimensions of environmental justice is the notion of recognition. Intentional non-recognition, misrecognition and exclusion of some groups is environmentally injustice. Deliberate non-recognition and exclusion of some groups (including their cultural, religious and identity distinctiveness) is usually tied with quest of oppressing, dominating, institutionally subordinating, disrespecting and marginalizing of those groups. This curiosity is to dominate or take away environmental resources and land of that specific groups or nations. It is noteworthy to raise here the question of Oromo, Agaw, Raya Asebo, Kimant people and so forth in Ethiopia. Their question is the question of recognition of their identity, culture, symmetric political relation, equity and selfdetermination regarding their environmental resources.

Furthermore, environmental problems and injustices such as pollution, toxic dumping, unfair distribution of environmental benefits and risks, lack of meaningful participation and representation in environmental decisionmaking, exclusion, oppression, domination and marginalization of poor people, local communities and discriminated people because of their ethnic ties are what cripple people's capability and functioning. These problems can cause conflicts between some group of society and between societies and government.

\section{The Importance of Environmental Justice Approach to Peace Building in Ethiopia}

Under the former topic, I tried to indicate the correlation between environmental justice and peace building, and implicitly, the significance of environmental justice dimension to peace building. Actually, different approaches and ways to build peace can be mentioned: political, socio-economic and ecological. Under this theme, accentuating on ecological aspects, I am going to briefly explain the worth of environment and environmental justice aspect in the process of building peace in Ethiopia. But this is not to reiterate the narrow concept of enhancing environmental cooperation taking the scarce resources as catalyst for building peace. Rather, it is to signify the idea that circumventing environmental injustices, to wit, restoring fairness, equity, recognition / inclusion, the right to decision making, participation, the principle of FPIC and fair and just compensation, the right of local people and so forth has a vital role to enhance conflict resolution and peace building within a country like Ethiopia.

As aforementioned, many conflicts incited in Ethiopia are environmental resource induced conflicts, though very often catalyzed by political wrangles. Nevertheless, significant attention was not given to environmental aspects of peace building by government and other stakeholders. Most of the time, government, political elites and activists, media and even intellectuals politicize every single of conflicts that happen in the country. This is what typically obscure environmental resource dimension of violent conflicts and instabilities between different groups people. Thus, even if political crisis has also a role to induce conflict and instability in the societies, ecological or environmental justice dimension should be recognized and great attention should be given to it if the government truly pursues warranting sustainable peace in the country.

This perspective is very important to recognize environmental resource-induced instability and stress the need to mitigate these risks to sustain the absence of violent conflicts through reducing the diverse and multifaceted environmental injustices and thereby facilitating environmental cooperation as well as recovery to build resilience in communities affected by quarrels. It fundamentally put forward sustainable solutions for the futurity of the people. According to scholars and practitioners curtailing environmental injustices during peace building processes contributes to the success of peace and conflict minimization ( Conca \& Wallace, 2009; Kostic, Krampe, \& Swain, 2012; A. Swain \& Krampe, 2011).

Two types of conflicts can be discerned here: conflict between two groups or societies, and between some group of people and government. As such, reducing injustices such as pollution, toxic dumping, coercive eviction of local people from their farm land and settlement in the guise of local and FDI investments and city expansion, unfair share of environmental advantages, oppression of some group of people to dominate and exploit their resources, forceful confiscation of one's land and resources around the border and so forth are very crucial to resolve conflicts between societies and between government and the victimized segments of people.

Seen from the slender concept of the advocators of environmental peace building, environmental justice approach also plays a great role to encourage people and even, adversaries to work together and march against problems like climate change injustices that stimulate resourse scarcity, shortage of water, rain, grazing land and the like ( Friends of the Earth Middle East,2008). Here, rather than leading to fight each other on scarce resources, 
they come together to solve their common problems by encouraging peaceful dialogue and influencing global, regional or local government and other stakeholder about climate change and limited resources, and to contribute their best such as conserving, preserving and restoring their environment. For some of Ethiopian people, particularly Oromo society, environment is everything. Besides socio-economic importance, environment has cultural and religious values. Thus, environmental aspect of peace building paves the way for people like this to resuscitate and reinforce their indigenous mechanism of conflict resolution and environmental protection which is very crucial to bring about sustainable peace in the country.

With respect to the expansion of cities like Addis Ababa and city-centered FDI, the surrounding people usually losing not only their green environment, farm land and settlements but also their culture and language. If they get appropriate compensation even, they lose their culture, language and way of life because they will be disseminated and so that living together and social bond will be vanished. People in the vicinities are also being bombarded by pollutions and toxic waste dumping that released from the cities and different industries therein. Local people surrounding the capital immensely contribute for the well being of the people living in the city; but, in reverse, these local people are suffering from the serious pollution and other environmental injustices induced by the people in the city. The residents of Addis Ababa and vicinities are suffering from the negative impacts of accumulated waste dumping on the streets and drains all around the city due to the inadequate waste management system (Gebre \& Van Rooijen, 2009; Worku and Giweta, 2018). For any Ethiopians, it is common to observe dwellers protesting and blaming these injustices through different Medias in the country.

Even very far from the cities, there are also different industries that are not only polluting the environment, river, lake and son on but also over consuming resources that can cause for shortage of water and drying of different lakes and rivers in the country. The above all environmental problems and injustices really weaken people's capability to attain what they value to be and do. Because of this, different conflicts have been impelled in such areas, which at the end, resulted in strong social insecurity and political turmoil. Besides political solution, the current government and other concerned bodies should provide environmental solution for these pressing problems. Recognizing this aspect of peace making is very important to enormously support political efforts in the process of ensuring lasting and sustainable peace throughout the country.

Generally, environmental justice dimension is very crucial to enhance peace for the reason that: $i$, it unmasks new aspects of building sustainable peace which really support widening the potential of political efforts in building peace and improving people's livelihoods as such ; ii, since, according to, for instance, Kappler (2012) and Richmond ( 2011), the sole emphasis on externally driven peace building process often leads to a lack of popular legitimacy, this environmental justice aspect help to develop this legitimacy through encouraging local people participation and employing the mechanism of conflict transformation that involves a peaceful means such as dialogue, negotiation and mediation; iii, it is indispensible not only for ensuring lasting peace through restoring fairness, justice, equity and peoples' capability, but also curbing environmental problems that are hindering the life of millions all over the world; iv, in reconstructing a war-ravaged society, the environment and natural resources often play a number of crucial roles in supporting economic recovery, the resettlement of displaced and enhancing livelihoods.

\section{Conclusion}

Environmental issues and peace building process are interlinked. As far as there are different environmental injustices that highly contribute for a range of violent conflicts, ensuring a meaningful environmental justice is one way or another signify resolving conflicts and restoring lasting and sustainable peace. However, in Ethiopia, there is no significant recognition of the role of environmental justice aspect in conflict resolution and peace building process. Government and other concerned bodies often see any conflicts that have been took place in the country from political point of view and so that pursue politically driven solution. A sole stressing on political dimension cannot be successful because many conflicts that have been happened in the country are environmental problems oriented and as such, it needs meticulous mitigation to sustain the absence of violent conflicts through reducing the diverse and multifaceted environmental injustices. Rather than a sole focus on externally driven political efforts, substantiating it with ecological dimension is very important to encourage cooperation and local people participation on conflict transformation and peace building process through peaceful means including dialogue, negotiation and mediation. Enhanced environmental governance and more effective natural resource control vigorously minimize the risk of violent conflict and instability. Besides supporting socio-economic and political endeavors in resolving conflicts and ensuring long-lasting and sustainable peace, this environmental approach is also highly significant to abate the manifold environmental injustices that are jeopardizing the lives and livelihoods of millions of Ethiopian people here and there.

For the above reasons, Ethiopian government should pay a great attention to it and play a lion share role to promote environmental justice practices, and reconsider his policies and strategy for peace building. This new dimension of peace making process can be used as an input for the newly established Ethiopian Reconciliation Commission. To be effective, government, policy-makers and practitioners should reassess policy and strategy 
mechanisms that address and challenge the root causes of conflicts and insecurity: new ways to restore environmental justice, to manage our natural resources more effectively, to address climate change and to repeal environmental dilapidation.

\section{References}

Amnesty International. (2014). Because I Am Oromo: Sweeping Repression in the Oromia Region of Ethiopia. Amnesty International October 2014; Index: AFR 25/006/2014.

Bullard, R. (2000). Dumping in Dixie: Race, Class, and Environmental Quality. $3^{\text {rd }}$ edition. Westview Press.

Burrows, K. and Kinney, P. (2015). Exploring the Climate Change, Migration and Conflict Nexus. International Journal of Environmental Research and Public Health; MDPI.

Center for International Human Rights Northwestern . (2019).Urgent Appeal to Special Procedures Regarding Ethiopias Lega Dembi Gold Mine2. 29 October 2019.

Conca, K., \& Wallace, J. (2009). Environment and Peacebuilding in War-torn Societies: Lessons from the UN Environment Programme's Experience with Postconflict Assessment. Global Governance: A Review of Multilateralism and International Organizations, 15(4), 485-504.

Curtis, D. (2012). 'Introduction: The contested politics of peacebuilding in Africa', in: Curtis, D and Dzinesa, G. (eds.). Peacebuilding, power, and politics in Africa. (pp. i-31). Ohio, Ohio University Press.

Figueroa, R and Mills, C. (2001). 'Environmental Justice', in Dale Jamieson (ed.), A Companion to Environmental Philosophy. ( pp.426-439). Blackwell Publisher Ltd

Galtung, J. (1969). Violence, Peace and Peace Research. Journal of Peace Research, 6(3), 167-191.

Friends of the Earth Middle East (FoEME). (2008). Environmental Peacebuilding Theory and Practice: A Case Study of the Good Water Neighbours Project and In Depth Analysis of the Wadi Fukin / Tzur Hadassah Communities.

Galtung, J. (1996). Peace by Peaceful Means: Peace and Conflict, Development and Civilization. Oslo: PRIO.

Gebre, G. and Van Rooijen, D. (2009). Water, Sanitation and Hygiene: Sustainable Development and Multisectoral Approacches; Urban Water Pollution and Irrigate Vegetable Farming in Addis Ababa. 34 ${ }^{\text {th }}$ WEDC International Conference, Addis Ababa, Ethiopia.

Grewal, S.(2003). Johan Galtung: Positive and Negative Peace. Auckland University of Technology.

Jamieson, D. (2001). A Companion to Environmental Philosophy. Blackwell Publisher Ltd.

Kappler, S. (2012). Everyday Legitimacy in Post-Conflict Spaces: The Creation of Social Legitimacy in BosniaHerzegovina's Cultural Arenas. Journal of Intervention and State building, 1-18. doi:10.1080/17502977.2012.655614.

Kok, A., Lotze, W. and Van Jaarsveld, S.(2009). Natural Resources, the Environment and Conflict. The African Centre for the Constructive Resolution of Disputes (ACCORD); Available from www.accord.org.za

Kostic, R., Krampe, F., \& Swain, A. (2012). 'Liberal State-Building and Environmental Security: the International Community Between Trade-Off and Carelessness', in A. Swain, J. Öjendal, \& R. Amer (Eds.), The Development and Security Nexus. Anthem Press.

Munnik, V. (2007). Solidarity for Environmental Justice in Southern Africa: A Report for Ground Work. Available from: http://www.groundwork.org.za

Nussbaum, M. (2000).Women and Human Development: The Capabilities Approach. Oxford University Press.

Richmond, O. P. (2011). A Post-Liberal Peace. London and New York: Routledge.

Schlosberg, D. (2007). Defining Environmental Justice: Theories, Movements, and Nature. Oxford University Press, New York Oxford.

Salih, Mohammed.(1999). Environmental Politics and Liberation in Contemporary Africa. London: Kluwer academic Publishers

Sen, A. (1999b). Development as Freedom. Anchor Books, a Division of Random House,

Inc. New York.

Steady, F. (2009). 'Environmental Justice Cross-Culturally: Theory and Praxis in the African Diaspora and in Africa', in Steady Filomina (ed.), Environmental Justice in the New Millennium: Global Perspectives on Race, Ethnicity, and Human Rights. (pp.47-64). New York: Palgrave Macmillan.

Swain, A., \& Krampe, F. (2011). 'Stability and Sustainability in Peace Building: Priority Area for Warfare Ecology', in G. E. Machlis, T. Hanson, Z. Špiric, \& J. E. McKendry (Eds.), Warfare Ecology .(pp. 199-210). Springer. doi:10.1007/97894-007-1214-0 14

United Nations (UN). (2009). Report of the Secretary-General on peacebuilding in the immediate aftermath of conflict. Sixty-third session of the General Assembly, A/63/881-S/2009/304. Available at: http://www.un.org/ruleoflaw/files/pbf_090611_sg.pdf

Webel, Ch. (2007). 'Toward a philosophy and metapsychology of peace', in Charles Webel and Johan Galtung (Eds), Handbook of Peace and Conflict Studies. (pp.3-13). London and New York: Routledge.

Werz, M. and Conley, L. (2012). Climate Change, Migration, and Conflict: Addressing complex crisis scenarios 
in the $21^{\text {st }}$ Century. Center for American Progress; Available from www.americanprogress.org

Worku Y and Giweta M.(2018). Can We Imagine Pollution Free Rivers around Addis Ababa city, Ethiopia? What were the Wrong-Doings? What Action Should be Taken to Correct Them? Journal of Pollution Effects \& Control.

World Commission on Environment and Development (WCED). (1987). Our Common Future; Brundtland report .New York: Oxford University Press. 